\title{
Influence of the Guided Inquiry Learning Model Assisted by a Two-stay Two-stray towards Chemistry Learning Outcomes of High School Students
}

\author{
*Dahlia Sofiyatun, Minarni R. Jura \& Sri M. Sabang \\ Pendidikan Kimia/FKIP - Universitas Tadulako, Palu - Indonesia 94119 \\ Received 21 December 2020, Revised 25 January 2021, Accepted 02 November 2021 \\ doi: $10.22487 / j 24775185.2021 . v 10 . i 4 . p p 208-212$
}

\begin{abstract}
This study aimed to determine the influence of the guided inquiry learning model assisted by two stays two strays toward students' learning outcomes on chemistry at SMA 7 Palu. The type of study was Pre-experimental with a one-shot case study design. The sample was prepared using the purposive sampling technique with Class XI Science 4 as the experimental class 1 and Class XI Science 2 as the experimental class 2. Both classes consisted of 28 students. The research instruments were the learning outcomes tests, student worksheets, and observation sheets validated theoretically and empirically. Learning outcomes were analyzed using inferential statistical analysis with a prerequisite test: normality, homogeneity, and t-test hypothesis test (right side). The results showed that the average learning outcomes for experimental class 1 was 62.32, and for experimental class 2 was 50.29, with standard deviations of 12.58 and 12.05, respectively. Hypothesis test obtained $t_{\text {count }}>t_{\text {table }}$ or $4.04>1.67$, so $H_{1}$ is accepted. The average learning outcomes of students in experimental class 1 with a guided inquiry learning model assisted by two stays two strays is higher than in the experimental class 2 with a guided inquiry learning model. Guided inquiry learning model assisted by two stays two stray influences learning outcomes of students at SMA 7 Palu.
\end{abstract}

Keywords: Guided inquiry, two stays two stray, learning outcomes

\section{Introduction}

The world of education is currently facing a considerable challenge, along with the development of science and technology, which is very fast becoming one of the main factors. To compensate for this development, of course, we need quality humans. One way that can be achieved to form a quality human is through world education (Miftachuddin et al., 2015). The quality of Indonesian people can be produced by providing quality education. One of the efforts to improve the quality of education is to improve the quality of learning (Sugesti et al., 2014).

The government is trying to improve the quality of learning by implementing the 2013 curriculum. The recommended learning approach and character of the 2013 curriculum is the scientific approach which is expected to produce qualified students in terms of attitudes, knowledge, and skills for each subject, especially chemistry (Trianto, 2010).

Chemistry is related to composition, structure, properties, change, dynamics, and energetics (Putri et al., 2014). Chemistry is also called the central science because it has a significant role among other sciences and is closely related to everyday life (Zeynep, 2013).

One of the materials in the subject of chemistry is colloid. The nature of the material is abstract, and a lot of memorization causes students to be less interested in learning and have difficulty understanding it (Karina et al., 2014).

Based on an interview conducted with a chemistry teacher at SMA Negeri 7 Palu, information was obtained that student learning outcomes in chemistry subjects with colloid material had a low success rate. The number of students who get low scores is one indication that most students do not understand colloid material because the presentation of colloid material is conveyed to students with the monotonous lecture method so that the learning process involves fewer students and ultimately makes students passive. Based on these problems, a learning model is needed that can make students active in the learning process (Wardani et al., 2016). The use of the suitable learning model is one of the crucial things as a means of conveying knowledge to students effectively and can increase student learning success (Assriyanto et al., 2014)

The learning model selection that will be used must pay attention to the characteristics and

*Correspondence:

Dahlia Sofiyatun

e-mail: dahliasofi97@gmail.com

(c) 2021 the Author(s) retain the copyright of this article. This article is published under the terms of the Creative Commons Attribution License 4.0, which permits unrestricted non-commercial use, distribution, and reproduction in any medium, provided the original work is properly cited. 
activities carried out by students during learning (Pramugarini et al., 2014). The accuracy of choosing a learning model or method in each teaching and learning process will determine the learning objectives planned and increase the student's academic ability (Kurniawan, 2013).

One learning model that can solve this problem is the guided inquiry learning model with two stays two stray assistance. The guided inquiry learning model with two stays two strays is the result of an analysis of guided inquiry learning, and two stays two strays combine the positive side of the two lessons to get better results.

One of the learning models suitable for chemistry learning is the guided inquiry learning model. This is because the guided inquiry learning model focuses on scientific activities to find and discover the meaning of learning systematically, critically, and logically and can help increase confidence and student learning outcomes (Yunus et al., 2013).

The guided inquiry learning model allows teachers to direct questions and multi-directional discussions that can lead students to understand the concept of lessons (Chairisa, 2016).

The steps of guided inquiry learning are the first step, namely formulating the problem; the teacher teaches students to determine an issue related to the lesson being delivered, then the students think of their answers. The second step is to propose a hypothesis; the teacher guides students to find quick solutions to the problems encountered. The third step is collecting data; students do a simple experiment. The fourth step is to test the experimental results with related facts and theories. In the fifth step, students make conclusions and present the results of their discussions before the class and make conclusions (Ambarsari et al., 2013).

Scientific-based learning models can help students understand the material independently. However, there is also a need for a way to provide opportunities for students to actively communicate, collaborate, and exchange ideas with other students in the class to support these students in understanding the material. Two stays two strays can be an option for this.

The purpose of using two stays two strays is to direct students to be active both in the discussion, question, and answer, looking for answers, explaining, and listening to the material presented by their friends. Two stay two strays can build student confidence, encourage student participation in learning, collaboration, and responsibility (Lapohea, 2014).

This two-by-two-guest structure can provide the opportunity for groups to share results and information with other groups. There are thinking and communicating activities. With such a learning model, students are expected to be actively involved individually and in study groups. With students' action in the classroom, it is hoped that a pleasant learning process will be created and increase student interest and motivation to learn so that their learning achievement increases (Zainuddin et al., 2014). Knowing that it is packaged attractively is expected to provide a different and imprinting learning atmosphere for students and help participants understand chemistry (Argandi et al., 2013).

This paper aims to present the examination of the effect of the two stays two stray assisted inquiry learning models applied to high school students.

\section{Methods}

This type of research is pre-experiment in this type of research, where there is no similarity of characteristics and no controlling variables (Sukmadinata, 2012). This study's design is a oneshot case study where the two experimental classes are given treatment and observed.

The population in this study were all students of class XI MIA SMA Negeri 7 Palu who were registered in the 2017/2018 school year. The research sample was taken from the population using the purposive sampling technique, which is a sampling technique based on specific considerations (Sugiyono, 2012). The sampling technique based on learning time is the same for the two experimental classes, the teaching teacher, the sample ability level is almost the same. Class XI MIA 4 is defined as experimental class 1 and XI MIA 2 as experimental class 2 .

\section{Results and Discussion}

The results of data analysis obtained during learning activities in the form of teacher and student activity observation sheets are presented in Tables 1 and 2 .

Based on the data in Table 2, it can be seen that the teacher's activities in learning are included in the outstanding category, and student activities in learning using the guided inquiry learning model with two stays two strays are had in the excellent category. This is supported by Sudjana \& Ibrahim (2002) that the ability required to implement the teaching and learning process is teachers' activeness in creating and growing learning activities according to the plans that have been prepared. The achievement percentage is $80 \%$ or in the good and excellent categories. 
Table 1. Results of teacher and student activity assessment in the experimental class 1 Experiment Class 1

\begin{tabular}{ccccccc}
\cline { 2 - 7 } Description & \multicolumn{3}{c}{ Teacher Activity } & \multicolumn{3}{c}{ Student Activities } \\
\hline Meeting & 1 & 2 & 3 & 1 & 2 & 3 \\
Percentage (\%) & 85 & 88.7 & 90 & 77.7 & 83.3 & 87.5 \\
Average (\%) & & 87.9 & & & 82.8 & \\
\hline
\end{tabular}

Table 2. Results of the assessment of student and teacher activities in the experimental class 2

\begin{tabular}{ccccccc}
\hline \multirow{2}{*}{ Description } & \multicolumn{6}{c}{ Experiment Class 2 } \\
\cline { 2 - 7 } & \multicolumn{3}{c}{ Teacher Activity } & \multicolumn{3}{c}{ Student Activities } \\
\hline Meeting & 1 & 2 & 3 & 1 & 2 & 3 \\
Percentage (\%) & 86.3 & 87.5 & 90 & 63.2 & 75 & 80.8 \\
Average (\%) & \multicolumn{3}{c}{87.9} & & & 73 \\
\hline
\end{tabular}

The assessment of teacher activities during the learning process is one of the supporters of the superiority of the guided inquiry learning model assisted by two stays two strays. The deficiencies at the first meeting in applying the guided inquiry learning model-assisted two stay two strays were corrected at the next meeting. This problem is resolved by giving directions to students to prepare themselves before learning begins. The teacher provides opportunities for students to practice the stages of the guided inquiry learning model with two stays two stray assistance, which will be implemented so that students can master the steps to reduce deficiencies that occur in previous meetings and learning time is more effective and efficient.

Student learning outcomes were obtained from a multiple-choice test after the overall learning for salt hydrolysis (Posttest). The post-test was carried out to determine the effect of the guided inquiry learning model with two stays two stray assistance on the learning outcomes of class XI MIA 4 and class XI MIA 2 students on colloid material. Data were obtained from experimental class 1 and experimental class 2 is presented in Table 3.

Table 3. Comparison of student learning outcomes in experiment class and control class

\begin{tabular}{ccc}
\hline \multirow{2}{*}{ Description } & \multicolumn{2}{c}{ Final Test } \\
\cline { 2 - 3 } & Experiment Class & Experiment Class 2 \\
\hline Sample value & 28.00 & 28.00 \\
Lowest Value & 40.00 & 27.00 \\
The highest score & 94.00 & 81.00 \\
Average score & 63.32 & 50.29 \\
\hline
\end{tabular}

The results of the calculation of the normality test for experimental class 1 obtained data $\mathrm{X}_{\text {count }}^{2}=$ 5.01 and $\mathrm{X}_{\text {table }}^{2}=7.81$. So it can be concluded that the data is usually distributed because it fulfills the criteria for normally distributed data, namely $\mathrm{X}_{\text {count }}^{2}$ $\leq \mathrm{X}_{\text {table, }}^{2}$ namely $5.01 \leq 7.81$. While the results of the experimental class 2 obtained data $\mathrm{X}_{\text {count }}^{2}=7.46$ and $\mathrm{X}_{\text {table }}^{2}=7.81$. So it can be concluded that the data is usually distributed because it fulfills the criteria for normally distributed data, namely $\mathrm{X}_{\text {count }}^{2} \leq \mathrm{X}_{\text {table, }}^{2}$ $7.46 \leq 7.81$. The results of the homogeneity test value of data use the $\mathrm{F}$ test (the same as two variances), and the most significant variance $=11.35$ and the most diminutive variance $=10.87$. Obtained the value of $\mathrm{F}_{\text {count }}=1.04$ and $\mathrm{F}_{\text {table }}=1.93$, so it can be concluded that the data meet the homogeneous data criteria, namely $\mathrm{F}_{\text {count }}<\mathrm{F}_{\text {table, }}$ namely $1.04<1.93$.

Before conducting inferential analysis using the t-test of one party, namely the right side, the prerequisite test is first carried out, namely the normality test and the homogeneity test. Normality testing aims to determine whether the data that has been obtained is normally distributed or not. In comparison, the homogeneity test is used to determine whether the two-class variants' data are homogeneous.

The results of inferential data analysis using a one-party t-test, namely the right side in both classes, namely the experimental class 1 and the 
experimental class 2, show that the data is usually distributed. The variance is homogeneous, and the one-party t-test analysis is the right side obtained $t$ count $>t_{\text {table }}=4.04$ and $t_{\text {table }}=1.67$ ) which shows that it is clear that $\mathrm{H}_{0}$ is in the rejection area so that $\mathrm{H} 0$ is rejected and $H_{1}$ is accepted, so the guided inquiry learning model-assisted two stays two strays has a more significant effect on student learning outcomes than the learning model guided inquiry without assistance two stays two stray. This is reinforced by the research results stated by Putri et al. (2015), which states that the guided inquiry learning model can increase student activity and student learning achievement.

The guided inquiry learning model is a learning model that helps students learn, assisting them to gain knowledge by finding their way. This model also includes finding the meaning, organization, and structure of ideas or ideas so that students gradually learn how to organize and conduct research to achieve learning goals (Wahyudi et al., 2013).

Two stays two strays are included in the guided inquiry learning model at the stage of analyzing data or testing hypotheses. In two stay two strays, each member of the group has the responsibility of studying the material provided by the teacher.

Several reasons can be used as the basis for determining that the two stays two strays assisted inquiry learning model is relatively better in providing opportunities for achieving maximum learning outcomes than the guided inquiry learning model without the assistance of two-stays two strays.

First, the inquiry learning model can make students learn from their experiences in solving problems and finding new ideas with teacher guidance. Teacher guidance and direction in guided inquiry learning activities help students know the direction of the learning process to guide students to see concepts from the material being studied and affect students' cognitive achievement (Arlianty et al., 2016).

Second, the inquiry learning model positively impacts teaching and learning activities, increases student activity during learning, improves the achievement of learning outcomes, and increases student participation in following the next lesson (Amanda et al., 2017).

Third, the characteristics of the inquiry learning model are suitable to be applied to concepts/materials that allow active students to analyze and solve problems systematically so that learning is student-centered. Student-centered learning will make students fully engaged in bringing out their ability to search and investigate systematically, critically, logically, and analytically so that they can formulate their findings with confidence. Learning that gives students a lot of opportunities is called meaningful learning. Meaningful learning will make it easy for students to remember the material and provide an in-depth understanding of concepts (Wardani et al., 2016).
The assessment of teacher activities during the learning process supports the superiority of the guided inquiry learning model with two stays two strays. The observation results show that the average teacher activity with the two stays two strays assisted inquiry learning model is $87.9 \%$ in the excellent category. In contrast, the teacher activity with the guided inquiry learning model without two stays two stray assistance is $87.9 \%$ with the perfect class. The guided inquiry learning model with two stays two stray assistance will help create learning that can strengthen positive interactions between students and students so that it can improve learning outcomes.

Based on this explanation, the guided inquiry learning model with two stays two strays are more influential than the guided inquiry learning model without the assistance of two stays two strays in achieving learning outcomes. This is supported by Matthew \& Kenneth (2013) in a study that stated that students' cognitive achievement is better using a guided inquiry learning model than using a conventional learning model. Thus, the guided inquiry learning model with the assistance of two stays two strays can be the right choice to use in the learning process of colloid material in class XI MIA SMA students.

\section{Conclusions}

Based on the results of research data analysis, it can be concluded that the guided inquiry learning model assisted with two stays two strays has a more significant effect on the learning outcomes of class XI MIA SMA Negeri 7 Palu on colloid material. This can be seen from the post-test average score of each class, namely the experimental class $1,62.32$, and experimental class 2, 50.29.

\section{Acknowledgments}

The authors would like to thank the principal of SMA Negeri 7 Palu and the chemistry subject teacher of SMA Negeri 7 Palu, and all helped me a lot in completing this research.

\section{References}

Amanda, R. R., Suharto, B., \& Mahdian. (2017). Meningkatkan aktivitas dan hasil belajar siswa dengan model pembelajaran inkuiri terbimbing pada materi redoks. Jurnal Inovasi Pendidikan Sains, 8(1), 43-51.

Ambarsari, W., Santoso, S., \& Maridi. (2013). Penerapan pembelajaran inkuiri terbimbing terhadap keterampilan proses sains dasar pada pelajaran biologi siswa kelas VIII SMP Negeri 7 Surakarta. Jurnal Pendidikan Biologi, 5(1), 8195.

Argandi, R., Martini, K. S., \& Saputro, A. N. C. (2013). Pembelajaran kimia dengan metode inquiry terbimbing dilengkapi kegiatan laboratorium real dan virtual pada pokok bahasan pemisahan campuran. Jurnal Pendidikan Kimia, 2(2), 44-49. 
Arlianty, W. N., Ashadi., \& Mulyani, S. (2016). Pembelajaran kimia menggunakan model inkuiri terbimbing dan predict observe expain (POE) ditinjau dari sikap ilmiah dan kemampuan berpikir kritis pada materi hidrolisis garam. Jurnal Kimia dan Pendidikan Kimia, 1(1), 41-51.

Assriyanto, K. E., Sukardjo, J. S., Saputro, S. (2014). Pengaruh model pembelajaran berbasis maslah melalui metode eksperimen dan inkuiri terbimbing ditinjau dari kreativitas siswa pada materi larutan penyangga di SMA Negeri 3 Sukoharjo tahun ajaran 2013/2014. Jurnal Pendidikan Kimia, 3(3), 89-97.

Chairisa, N., Sholahuddin, A, \& Leny. (2016). Perbedaan literasi ilmiah dan hasil belajar pada materi sistem koloid antara pembelajaran yang menggunakan model inkuiri terbimbing dengan metode eksperimen riil dan eksperimen animasi. Jurnal Inovasi Pendidikan Sains, 7(2), 156-175.

Karina, Y. D., Haryono., \& Ariani, S. R. D. (2014). Penerapan model pembelajaran team games tournament (TGT) dilengkapi teka-teki silang dan kartu untuk meningkatkan aktivitas dan prestasi belajar pada materi koloid kelas XI IPA 1 SMA Negeri 1 Banyudono tahun pelajaran 2013/2014. Jurnal Pendidikan Kimia, 3(3), 8288.

Kurniawan, A. D. (2013). Metode inkuiri terbimbing dalam pembuatan media pembelajaran biologi untuk meningkatkan pemahaman konsep dan kreativitas siswa SMP. Jurnal Pendidikan IPA Indonesia, 2(1), 8-11

Lapohea, A. Z. (2014). Penerapan model pembelajaran kooperatif tipe two stay two stray untuk meningkatkan hasil belajar siswa pada materi logika matematika. Jurnal Elektronik Pendidikan Matematika Tadulako, 1(2), 121133.

Matthew, B. M., \& Kenneth, I. O. (2013). Study on the effect of guided learning teaching method on students achievement in logic. International Researcher, 2(1), 135-140.

Miftachuddin, Budiyono, \& Riyadi. (2015). Efektivitas model pembelajaran two stay two stray dengan tutor sebaya dalam pembelajaran matematika pada materi bangun datar ditinjau dari kecerdasan majemuk peserta didik kelas VII SMP Negeri di Kebumen tahun pelajaran 2013/2014. Jurnal Elektronik Pembelajaran Matematika, 3(3), 233-241.

Pramugarini, D. Y., Kusmayadi, T. A., \& Riyadi. (2014). Eksperimentasi model pembelajaran two stay two stray (TS-TS) dan think-pair-share (TPS) dengan pendekatan pendidikan matematika realistik (PMR) ditinjau dari aktivitas belajar matematika. Jurnal Elektronik Pembelajaran Matematika, 2(3), 250-259.

Putri, Y., Suratno., \& Asyiah, I. N. (2015). Pengaruh model pembelajaran inkuiri terbimbing (guided inquiry) dengan menggunakan metode eksperimen terhadap aktivitas dan hasil belajar IPA-biologi siswa kelas VIII SMA Negeri 2 Maesan Bondowoso. Jurnal Pendidikan Biologi, 4(2), 163-172

Sudjana, N., \& Ibrahim. (2009). Penelitian dan penilaian pendidikan. Bandung: Sinar Baru Algensindo.

Sugesti, F. E., Budiyono., \& Subanti, S. (2014). Eksperimentasi model pembelajaran kooperatif tipe structured numbered heads $(\mathrm{SNH})$ dan two stay two stray (TSTS) dengan pendekatan realistic mathematics education (RME) pada prestasi belajar matematika ditinjau dari adversity quotient (AQ) siswa. Jurnal Matematika dan Pendidikan Matematika, 4(1), $1-10$.

Sugiyono. (2013). Statistik untuk penelitian. Bandung: Alfabeta.

Sukmadinata, N. S. (2012). Metode penelitian pendidikan. Bandung: PT. Remaja Rosda Karya.

Trianto. (2007). Model-model pembelajaran inovatif berorientasi konstruktivistik. Jakarta: Prestasi Pustaka.

Wahyudi, L. E., \& Supardi, Z. A. I. (2013). Penerapan model pembelajaran inkuiri terbimbing pada pokok bahasan kalor untuk melatihkan keterampilan proses sains terhadap hasil belajar di SMAN 1 Sumenep. Jurnal Inovasi Pendidikan Fisika, 2(2), 62-65.

Wardani, S., Setiawan, S., \& Supardi, K. I. (2016). Pengaruh pembelajaran inkuiri terbimbing terhadap pemahaman konsep dan oral activities pada materi pokok reaksi reduksi dan oksidasi. Jurnal Inovasi Pendidikan Kimia, 10(2), 17431750 .

Yunus, F. M \& Ali, Z. M. (2013). Attitude towards learning chemistry among secondary students in Malaysia. Journal of Asian Behavioural Studies, 3(11), 122-132.

Zainuddin., Budiyono., \& Sujadi, I. (2014). Eksperimentasi model pembelajaran kooperatif tipe two stay two stray dan numbered heads together pada materi pokok fungsi ditinjau dari kecerdasan interpersonal siswa kelas VIII SMP Negeri se kota Surakarta. Jurnal Elektronik Pendidikan Matematika, 2(2), 121-130.

Zeynep, T., \& Alipasa, A. (2013). Effect a virtual chemistry laboratory on students achievement. Education Technology Society, 16(1), 159-170. 